\title{
MEDICAL NEGLIGENCE IN ANCIENT LEGAL CODES
}

\author{
J C Zietsman (Stellenbosch University)
}

\begin{abstract}
In Roman Law the Lex Aquilia provided a regulation relating to loss or damage. The first chapter specified punishment for the killing of another's slaves and four-footed animals used in an agricultural community - animals that could collectively be referred to as "livestock". The third chapter covered all cases of loss caused by burning, breaking or destroying property (usserit, frangerit, rumperit). This article discusses the interpretation of the Lex Aquilia by Roman jurists with special reference to texts dealing with liability in terms of negligent medical treatment in comparison with similar texts from the ancient Mesopotamian legal codes.
\end{abstract}

\section{The concept of liability for negligence in Roman Law}

In Roman Law the Lex Aquilia, dated circa 287 BC, provided a fundamental regulation relating to loss or damage sustained through the killing or injury of slaves and animals or the destruction of other property (Dannenbring 1968: 213-214). (It is important to note that this statute did not deal with the killing of or injury to free persons.) The interpretations and applications of the Lex are extensively discussed in the Digesta or Digest which forms a part of the Justinian Code or Corpus Iuris Civilis. Published in 533 AD the fifty volumes of the Digest consist of extracts, arranged according to subject, from the most important jurists from the classical era of Roman Law, roughly from the start of the Principate (27 BC) until the death of the emperor Alexander Severus in 235 AD. The subject for the second chapter of Digest Book 9 is Ad Legem Aquiliam. In my discussion I shall refer to extracts from the famous jurists Gaius, Ulpian and Paul and also the less known Labeo and Alfenus, who all feature in the Digest.

Replacing all previous legislation dealing with damage to property, the Lex Aquilia had its origins in the first, rather primitive, codification of Roman Law, the so-called Leges Duodecim Tabularum ("Laws of the Twelve Tables") published in $450 \mathrm{BC}$. In these laws provision was made for retaliation in kind (talio in Latin - or the "eye for an eye" philosophy typical of most ancient legal codes), or an option of monetary compensation for damage caused (R.O.L. III: Tabula 8:2-4; Warmington 1967:476-77).

The Lex Aquilia, however, introduced a far more advanced approach. The first chapter of the Lex specified punishment for the killing of another's slaves and animals that were of importance for an agricultural community - animals that were collectively referred to by the Lex as "four-footed beasts of the class of cattle", that is, not quadrupeds as such but those grazing animals that forage in groups. Praetorian edicts limited these to include only horses, donkeys, mules, sheep, goats, pigs and, of course, cattle (Just. Inst. 4.3.1). The defendant was fined to pay as compensation an 
amount equal to the highest value that the object had had during the year before it was killed (Gaius 3.210; Digest 9.2.2 pr.) $)^{1}$

The third chapter was phrased in more general terms and covered all cases of loss caused to another by burning, breaking or destroying property (usserit, frangerit, ruperit). In this case compensation was calculated according to the value in diebus triginta proximis, ${ }^{2}$ probably within the last thirty days before the damage took place. It is interesting that the word plurimi ("highest") was not included in this chapter of the Lex, but both Gaius and Justinian ${ }^{3}$ refer to an interpretation by the first century $A D$ jurist Sabinus who held that the law should be interpreted as if it had been inserted, "the legislator having thought it sufficient to have used the word in the first chapter". 4

Although the first chapter of the Lex Aquilia is limited to a particular kind of damage done to particular kinds of property, the third chapter shows a striking advance: it has a general concept of loss (damnum) caused in ways which are described with such generality that any physical damage to property could be held to be covered: if usserit (burning) and fregerit (breaking) were limited, ruperit proved to be elastic. For Gaius, probably the most prominent jurist from the 2 nd century AD, it includes cutting, bruising, spilling, and all kinds of damage, destruction or spoiling. ${ }^{5}$ De Zulueta ${ }^{6}$ argues that the specific cases mentioned in Chapter 1 would have fallen under Chapter 3 had they not been specified separately. Gaius therefore simply summarises the third chapter in such general terms as "the third chapter deals with all other damage to property". This for example includes the killing of or injury to animals excluded in Chapter 1, such as dogs and also wild animals kept in captivity.

The method of reckoning back to the highest value within the previous year or within the last thirty days can be explained if it is considered that the killed slave would already be valueless at the moment of his death or an injured slave less valuable when he had been injured, so it was the intention to refer to a time when he was still a valuable asset to his owner. ${ }^{7}$ This means that an owner sometimes recovered more than the loss that had been inflicted on him.

Another advance is the first, rather halting, appearance of compensation for the actual damage instead of penalty for wrong. Not that from the point of view of its authors the actio legis Aquiliae could have been anything but penal. Early jurisprudence marked it once and for all with the characteristics of an actio poenalis. This means that the actio legis Aquiliae was penal in its legal characteristics, but compensatory in its normal result ${ }^{8}$ in that it compensated for damage or loss.

The action in terms of the Aquilian law is still valid in the South African legal system and specifically - as in Roman Law - deals with the delict of damnum iniuria

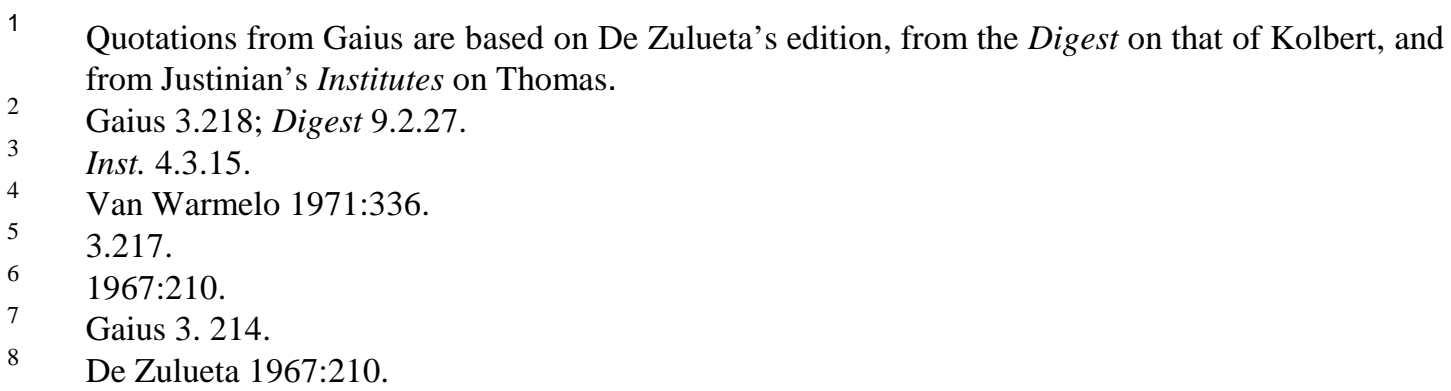


datum, or "unlawful damage to property" where iniuria is used in its proper sense of "unlawful act": omne quod non iure fit, literally "everything that is not done legally."

We should distinguish between iniuria in this context and iniuria as the separate delict of injury to another's personality, which is also part of South African law. It can take several forms, e.g. libel, insult, gross offence or outrage upon dignity or decency. In Roman Law physical injury to a free person (that is, somebody who is not a slave) is also regarded as iniuria in this sense: obviously injury to a free person cannot be calculated or valued in terms of monetary loss as in the case of a slave. This topic however falls beyond the scope of this article.

The act of causing loss or damage (damnum) must have been done (datum) wrongfully or unlawfully, iniuria, that is, without justification or lawful excuse. ${ }^{10}$ The late Republican jurists interpreted iniuria in terms of dolus (malice) and culpa (intent). ${ }^{11}$ Furthermore, they maintained that the wrongdoer's positive act (not a mere omission or lack of preventive action) had to harm the other's object directly damnum corpori corpore datum, literally "damage done to a body by a body" constituting an immediate physical link between cause and result.

During the classical period of Roman Law Aquilian liability was extended to include cases where the loss was caused by an omission on the part of the wrongdoer, a failure to provide against harmful consequences that ought to have been foreseen ${ }^{12}-$ that is, culpa in the sense of negligence - or, although by an act, in such a way that the wrongdoer did not directly and physically interfere with the harmed object, but with another person or thing instead which in turn occasioned the loss. ${ }^{13}$

In order to establish liability in such cases, the praetor (the official responsible for the administration of the legal system) issued edicts interpreting the intention of the Lex Aquilia and allowed a claimant a so called analagous action or actio utilis (ad exemplum legis Aquiliae), also called an actio in factum. ${ }^{14}$ The ius edicendi (or the right to issue edicts) allowed the praetor to interpret Roman law and publish additions to its applicability; these edicts soon created a secondary source of law apart from the Leges Duodecim Tabularum. In this way especially during the latter half of the Republican era Roman Law developed into the vast legal system that was eventually codified during the reign of Justinian in the 6th century $\mathrm{AD}$ and became the ius commune of post-Medieval Europe. Some scholars call it "Imperial Rome's most lasting contribution to civilisation". ${ }^{15}$

The practicality of and necessity for allowing an analagous action is clearly illustrated by Gaius. ${ }^{16} \mathrm{He}$ mentions cases of a person who shuts up and starves to death another man's slave or cattle, or drives his animals so hard that they collapse and die, or persuades another's slave to climb a tree or to go down a well and he falls and is killed or physically injured in climbing up or down - surely the act was not

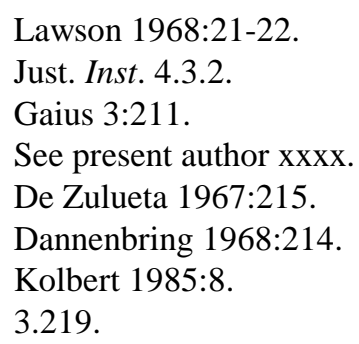


inflicted by the defendant's body, but damage has been caused and the analagous action should be allowed. ${ }^{17}$

Two final examples taken from the Digest illustrate the precision of Roman Law, taking into consideration all possible scenarios for establishing liability for negligence: a text from Paul states that if a tree-trimmer threw down a branch from a tree and killed a passing slave - and the same principle would apply to a man working on a scaffolding - he is clearly liable if it falls on public land and he did not call out so that the accident could be avoided. ${ }^{18}$

At first sight it seems that there is a hint here that had this occurred on private land or at a place where the slave was probably not supposed to be, the tree-trimmer would not have been guilty of culpa. But the text continues with a reference to a certain Mucius who said that if this occurred on private land, there could be an action for culpa; for it is culpa not to have foreseen what a careful person could have foreseen, or to have called out when the danger could not be avoided.

The effect of this reasoning is that there is not much difference between a path over public or private land - paths quite commonly ran through private land, for instance where a servitude of the right of using a footpath (iter) existed. ${ }^{19}$ But if there was no path, a tree-trimmer could only be liable for dolus (malice, intent) if for instance he had aimed the branch at someone he saw passing - but he would not be liable for culpa since he could not be expected to foresee that somebody might pass under the tree.

This distinction is confirmed by Paul in another text: those who make pits in order to catch bears and stags are liable in terms of the Lex Aquilia if they made them on paths and something fell in and was thereby lowered in value. But if they made them in other places where they are usually made, they are not liable. ${ }^{20}$ What is interesting in this text, however, is that Paul continues to state expressly that a plaintiff would not be successful if he could have avoided the danger ${ }^{21}-$ hinting at the possibility of contributory negligence that I have discussed in a previous article. ${ }^{22}$

\section{Medical negligence}

Although ancient legal codes do not deal with medical matters as such (and for obvious reasons I am not referring to the Hippocratic Oath here), I did find some references to situations describing what I would like to term "medical negligence" and have selected six texts from Roman Law dealing with this aspect.

The first two concern the administering of drugs. Ulpian ${ }^{23}$ describes a situation where a midwife gives a drug to a woman who then dies of it, and he refers to Labeo who distinguishes between two scenarios:

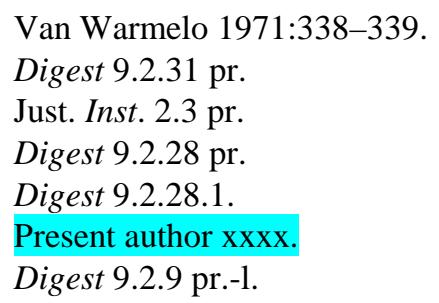


If she administered it with her own hands, she is held to have slain killed (occidisse), but if she gave it for the woman to take herself, an action in factum should be given. This view is correct, says Ulpian, since she furnished the cause of death rather than slew. If a person, using force or persuasion, injects a drug into another either orally or by syringe, or rubbed him with a foul poison, he is liable under the Lex Aquilia, just like the midwife who personally administers a drug.

In justifying Labeo's decision, Ulpian notes the difference between "slaying" (occidere) and "furnishing the cause of death" (causam mortis praestare). This distinction, which seems to have been favoured especially by the jurist Celsus in the early second century $\mathrm{AD},{ }^{24}$ is also discussed by Ulpian in another text: ${ }^{25}$

Celsus says that there is a great difference between administering death and furnishing the cause of death, in that a person who furnishes the cause of death is liable not in an Aquilian action but by one in factum. Thus he mentions a person who gave poison as a drug; Celsus says that he furnished the cause of death, just like a person who held out a sword to a lunatic; for this person is not liable under the Lex Aquilia, but in factum. But if a person hurled someone from a bridge, Celsus says that whether he died by the blow itself or was immediately drowned or was exhausted and died when overcome by the river's current, there is liability under the Lex Aquilia, just as if someone dashed a boy against a rock.

Clearly the issue here is that the Lex Aquilia defines damage as loss caused corpori corpore: the law requires a direct physical link between the action causing damage and the actual damage. In legal terms this is called the element of causation. ${ }^{26}$ Handing someone a deadly poison which the victim then takes himself and dies, means to furnish the cause of death, just as it is when handing a sword to a lunatic who then kills himself or somebody's slave with it - but it is not considered as slaying or killing in terms of the first chapter of the law - there is no direct physical link between the handing over and the death of the victim, unlike in the case of Celsus' gruesome example of dashing someone against a rock. But there is damnum; therefore, the analogous (in factum) action will be used to establish the defendant's liability.

It is perhaps interesting to note just briefly here that the case of the lunatic killing somebody else is a bit more problematic ${ }^{27}$ since lunatics can obviously not be held accountable for their deeds. Here again an in factum action would probably succeed against the person who handed a dangerous weapon to the lunatic.

The next two texts deal with a doctor's duty of care. Ulpian ${ }^{28}$ quotes the first century $\mathrm{AD}$ jurist Proculus who says that if a doctor unskillfully (imperite) operates on a slave, an action is available either on the contract for hiring of services (ex locato)

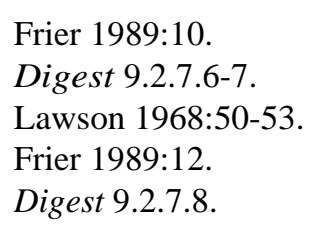


or under the Lex Aquilia. Gaius ${ }^{29}$ adds that the same applies if a doctor uses a drug improperly (Justinian ${ }^{30}$ talks about giving the patient the wrong medicine). Also, if he operated correctly and then abandoned treatment, he is guilty of culpa.

It seems that two issues are at stake here; firstly, it could be that normal professional medical standards imposed certain general duties on a doctor in treating a sick slave, but secondly, that these duties were surely also legal standards imposed on doctors. A doctor is liable in medical terms if he operates unskillfully, and also legally especially if he fails to follow up on the operation, that is, if he fails to do something. This is confirmed by Ulpian in a different text ${ }^{31}$ where he categorically says that doctors are liable in factum for careless treatment of any kind.

Whether a doctor is being held to a higher duty of care because he is a doctor, or because he is offering medical treatment ${ }^{32}$ does not make any difference - his carelessness amounts to imperitia (lack of skill) which Justinian ${ }^{33}$ regards as negligence in terms of the Lex Aquilia. The same would be the case in the following scenario: ${ }^{34}$

If your slave be crushed by runaway mules which the muleteer is unable to control by reason of his lack of skill, the muleteer is guilty of negligence; as also when he cannot keep them in check by reason of his lack of strength, if a stronger man could have done so. The same was accepted as law also in respect of one who, when riding a horse, could not check its rush through lack of strength or lack of skill.

Finally, Roman Law also allows for the obvious which is not necessarily always expressed in as many words. A text from Alfenus ${ }^{35}$ states:

If a slave had died from wounds and this did not occur because of a doctor's lack of knowledge or his master's carelessness, action is properly brought for his wrongful slaying.

Obviously the owner of the wounded slave in question thought that the wounds were not very serious and decided not to have the slave treated by a doctor. One should remember that slaves had an economic value and that a responsible owner would not lightly disregard serious injury to his slave. In this case the slave was in fact much more seriously injured than it appeared and soon died of the untreated wounds. Since there was no unskilled doctor involved and we can assume that the owner did not act carelessly by not having the slave treated, the owner will have recourse to the Lex Aquilia for the killing of the slave by the defendant. What is interesting in this case is that there is an obligation on the owner to take proper care of his slave and although he failed to consult a doctor it is not regarded as carelessness as such.

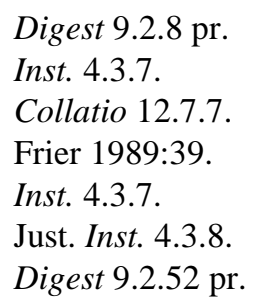


It is of course also possible to interpret this text as if the owner did have the slave treated but that the slave nevertheless died. Either way the defendant would be liable for killing the slave, and not for wounding. This is substantiated by a text from Paul $^{36}$ who puts the converse case:

If a slave is wounded, but not mortally, and he dies from neglect (negligentia), the action will be for wounding, not killing.

So, if a slave dies because of the owner's negligence or carelessness by not treating the slave's wounds properly, the defendant can only be held liable for wounding the slave and not for killing. Clearly the element of causation determines the extent of liability: in Paul's text the defendant wounded the slave, but the slave died as a result of the owner's neglect in the treatment of the slave.

Loss as a result of negligent conduct or even failure to take proper care was just as much a part of the early legal codes of Mesopotamia as was the case in Roman Law. Especially in the Hammurabi Code (circa $1750 \mathrm{BC}$; hereafter abbreviated $L H$ ) references are found to a variety of instances dealing with people who are negligent in their professions: amongst others we meet a gardener, ${ }^{37}$ a barber, ${ }^{38}$ a boatman, ${ }^{39}$ a shepherd, ${ }^{40}$ a woman innkeeper, ${ }^{41}$ and even a builder. ${ }^{42}$

Before I continue this part of my discussion I should mention in passing that the concept of liability for damage in terms of negligent conduct or an omission also appears in other early legal codes. Exodus 22:7-12 deal with the safekeeping of a neighbour's property. If the goods kept in safekeeping are stolen and no thief can be found, the person from whose safekeeping the goods had been stolen had to make restitution to the owner - in some cases double the value of the stolen goods. This is presumably an instance of failure to take proper care, an omission on the part of the safekeeper, constituting liability for loss.

Our earliest collection of Egyptian Law, the so-called Demotic Law Code of Hermopolis, dates to the 3rd century BC. It is commonly understood to be a later development of a legal codification begun under Darius I of Persia (519 - 503 BC), but is perhaps better understood as a legal manual that governed life in a rural, medium-sized Egyptian community. ${ }^{43}$ Fragment II: 9 deals with a lessee who received seed from the landlord but did not cultivate the fields that he had taken on lease and "takes away the seed after the fields have been irrigated [i.e. to receive or get water]". ${ }^{44} \mathrm{He}$ would be summoned to pay the rent and the cost of the seed in terms of his lease. Although it is not expressly mentioned, it seems to me that this text deals with liability in terms of his negligence or failure (an omission) to cultivate the fields in terms of the agreement. This view seems to be substantiated by Fragment II:10-11,

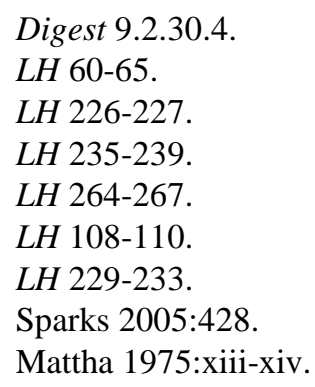


stating that had the fields not been irrigated as a result of lack of rain, the lessee would not be liable for the rent but had to return only the seed. ${ }^{45}$

To return to Mesopotamia: I also found three sets of texts dealing to some extent with medical negligence in terms of the discussion so far. Although these texts are much less detailed than their Roman counterparts they contain the same basic philosophy of law.

Early Mesopotamian society consisted of three classes or status groups: free men, commoners and slaves. In some families of the highest class it was customary for a new-born child whose mother was unable to suckle the child, to be entrusted to the care of a wet nurse who rendered this service and reared the child for a period of two or three years, ${ }^{46}$ with an obligation on the father of the child to bear the cost of the rearing of the child, obviously just as he would have had to provide for had the mother reared the child at home: ${ }^{47}$

If a man gives his child for suckling and for rearing but does not give the food, oil and clothing rations (to the caregiver) for three years, he shall weigh and deliver ten shekels of silver for the cost of the rearing of his child, and he shall take away the child.

A much more complex legal situation is set out in the following text: ${ }^{48}$

If a man gives his son to a wet nurse and that child then dies while in the care of the wet nurse, and the wet nurse then contracts for another child without the knowledge of his father and mother, they shall charge and convict her, and because she contracted for another child without the consent of his father and mother, they shall cut of her breast.

Firstly, this text deals with a person's capacity to enter into contracts; of special interest is that it is the only example in the Laws of Hammurabi of a restriction on a person's ability to enter into a contract freely. ${ }^{49}$ The issue here is that the wet nurse, who contracted to care for the child who died while he was in her care, is not permitted to contract to care for another child without the consent or permission of the child's parents, that is - without the knowledge of the parents of any new child which she proposes to take. In other words, she must reveal to them that she has lost a previous child. The penalty for a breach of this law is the loss of her breasts. ${ }^{50}$ Although the singular form is used for "breast", the text does not say "one breast" (the loss of which might already prevent the woman's employment), so the word is here preferably to be understood in a collective sense as meaning both breasts. ${ }^{51}$

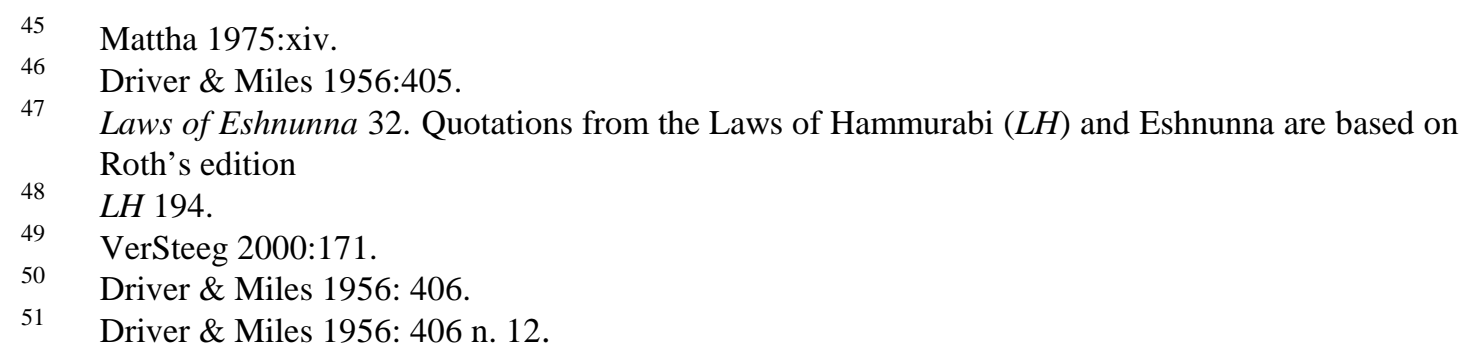


Secondly, however, it is clear that a contractual duty of care or responsibility for bringing up the child is implicitly imposed on the wet nurse and that lack of care (imperitia in Roman Law) is also addressed: the breasts which have failed to keep the child alive are destroyed and the wet nurse is effectively prevented from repeating her offence.

A number of laws in the Hammurabi Code ${ }^{52}$ refer to various aspects of the work of a physician and also deal specifically with the liability of doctors who cause injury or death while performing surgical procedures. ${ }^{53}$ LH 215-217 and 221-223 determine the doctor's fee for performing surgery or treating a patient's broken bone or injured muscle (or "ligament" as VerSteeg translates the word) - the higher the patient's status (i.e. free man, commoner or slave), the higher the fee. But these laws also impose higher damages when the patient is a free man and lower when the victim is either a commoner or a slave: ${ }^{54}$

If a physician performs major surgery with a bronze lancet upon a free man and thus causes the free man's death, or opens a free man's temple with a bronze lancet and thus blinds the free man's eye, they shall cut off his hand.

LH 219-220 describe the same procedures being performed on the slave of a commoner: if the physician causes the slave's death, he shall replace the slave with a slave of comparable value, and if he blinds the eye of the slave, he shall weigh and deliver silver equal to half his value.

When the surgery causes blindness or the death of a free man, the penalty is amputation of the hand, which means that the doctor loses his ability to remain in practice: as in the case of the wet nurse, the offending organ is punished for the satisfaction of the patient and the general public is at the same time protected against future risk at his hands. ${ }^{55}$

If a slave dies as a result of surgery, the doctor has to replace the slave, and for blinding the slave he has to pay one-half the value of the slave as compensation, presumably to the owner of the slave. Although the text mentions the blinding of one eye only, it could be possible that the penalty would be doubled if both eyes were destroyed. ${ }^{56}$

In comparison to the Digest texts dealing with liability for unskillful or careless medical procedures in Roman Law, it is interesting that the Laws of Hammurabi ${ }^{57}$ do not specify the damages that were due in cases where a physician set a broken bone or operated on a muscle unsuccessfully. ${ }^{58}$ It may possibly be due to the fact that failure in these procedures did not usually have a fatal result and could be repeated until success was achieved. ${ }^{59}$

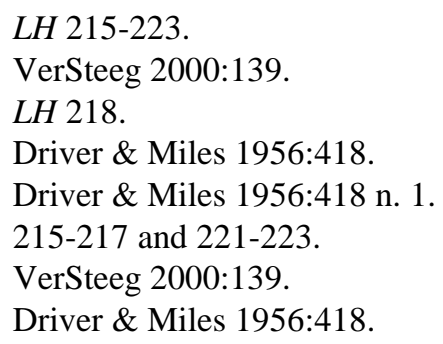


The final two texts deal with the services of a veterinarian, literally called "the doctor of an ox or a donkey". The first ${ }^{60}$ prescribes the fixed payment for a successful operation:

If a veterinarian performs major surgery upon an ox or a donkey and thus heals it, the owner of the ox or of the donkey shall give the physician as his fee one sixth of a shekel of silver.

But if the procedure is unsuccessful and causes the death of the animal, the amount payable as compensation is fixed: ${ }^{61}$

If he performs major surgery upon an ox or a donkey and thus causes its death, he shall give one quarter of its value to the owner of the ox or donkey.

It seems as if there is again - as in the case of the wet nurse - an implicit duty of care imposed on the veterinarian. For that reason he is fined to pay compensation if his operation causes the death of the animal.

A final point of interest is that while no specific word is used in the original text for the doctor's fee, that of the veterinary surgeon is called his "hire", which is a word used elsewhere for a shepherd's or an artisan's wage. This distinction suggests that the veterinary surgeon was regarded as an ordinary craftsman. ${ }^{62}$

To conclude: although the concept of compensation for damage instead of penalty for wrong in Mesopotamian society was not as developed as it was in terms of Roman law, both these aspects did feature in the early legal codes. It is however interesting that the application of these aspects as well as the severity of the penalty are far more linked to the civil status of the injured party than was the case in Roman law, granted that Roman Law deals with physical injury to a free man under the totally different set of rules of the actio iniuriarum.

If a free person in Mesopotamia suffers damage or loss, the offending organ is punished: the wet nurse loses her breasts and the doctor his hand. If a slave dies after an operation or loses his eyesight, or if an operation on an animal results in its death, the surgeon's penalty is compensatory. The basic philosophy of law is universal: damage - whether as a result of negligence, carelessness, lack of skill or knowledge, or failure to act, whether in Mesopotamia, Israel, Egypt or Rome - will not go unpunished.

\title{
Excursus: negligence in contemporary medical practice
}

One does from time to time read or hear about actions brought against negligent doctors, more typically in the USA but even in South Africa. According to a surgeon whom I recently met, his insurance premium against such actions amounts to R 80000 per year. Before he even touched his "bronze lancet" to perform major

\author{
LH 224 \\ LH 225. \\ Driver \& Miles 1956:421.
}


surgery on me, I had to sign a patient consent form in order to cover the surgeon against a possible law suit, acknowledging the following:

- The doctor has explained my medical condition and the proposed procedure.

- I understand the risks of the procedure, including the risks that are specific to me, and the likely outcomes.

- The doctor has explained other relevant treatment options and their associated risks.

- The doctor has explained my prognosis and the risks of not having the procedure.

- I was able to ask questions and raise concerns with the doctor about my condition, the procedure and its risks, and my treatment options.

- My questions and concerns have been discussed and answered to my satisfaction.

- I understand that no procedure can be guaranteed $100 \%$.

- I understand that photographs or video footage may be taken during my operation. These may then be used for teaching health professionals but I will not be identified in any photo or video.

- $\quad$ On the basis of the above statements, I REQUEST TO HAVE THE PROCEDURE.

I duly signed on the dotted line. Fortunately for both of us the surgeon still has his right hand and I have regained the use of my left hand.

\section{BIBLIOGRAPHY}

Dannenbring, R. 1968. Roman Private Law. Durban: Butterworths.

De Zulueta, F. 1946 [1974]. The Institutes of Gaius. Part I: Text with critical notes and translation. Oxford: University Press.

De Zulueta, F. 1953 [1967]. The Institutes of Gaius. Part II: Commentary. Oxford: University Press.

Driver, G.R. \& Miles, J.C. 1952 [1956]. The Babylonian Laws. Volume I: Legal commentary. Oxford: Clarendon Press.

Frier, B.W. 1989. A casebook on the Roman Law of Delict. Atlanta: Scholars Press.

Kolbert, C.F. (trans.) 1979 [1985]. Justinian: The Digest of Roman Law. Harmondsworth: Penguin.

Lawson, F.H. 1950 [1968]. Negligence in the Civil Law. Oxford: Clarendon Press.

Mattha, G. 1975. The Demotic Legal Code of Hermopolis West. Institut Francais d'Archéologie Orientale: Cairo.

Present author Xxxxxx 
Roth, M.T. 1997 (2nd ed.). Law Collections from Mesopotamia and Asia Minor. Atlanta: Scholars Press.

Sparks, K.L. 2005. Ancient texts for the study of the Hebrew Bible: a guide to the background literature. Peabody, MASS: Hendrickson Publishers.

Thomas, J.A.C. 1975. The Institutes of Justinian: Text, translation and commentary. Juta: Cape Town.

Van Warmelo, P. 1971. 'n Inleiding tot die studie van die Romeinse Reg. Balkema: Kaapstad.

VerSteeg, R. 2000. Early Mesopotamian Law. Durham: Carolina Academic Press.

Warmington, E.H. (transl.) 1938 [1967]. Remains of Old Latin. Volume III: The Twelve Tables. Loeb Classical Library. London: Heinemann. 